\title{
Mineralogical Analysis of Mortars in the Walls of Ávila (Spain) and Its Surroundings
}

\author{
Isabel Sonsoles de Soto García ${ }^{1}\left(\mathbb{D}\right.$, María de los Reyes de Soto García ${ }^{2}$ and \\ Rosario García Giménez ${ }^{3, *(D)}$ \\ 1 Departamento de Ciencias, Escuela Técnica Superior de Ingenieros Agrónomos, Universidad Pública de \\ Navarra, 31006 Pamplona, Spain; isabelsonsoles.desoto@unavarra.es \\ 2 Instituto de Arqueología de Mérida (CSIC-Junta de Extremadura), Plaza de España, 15, 06800 Mérida, Spain; \\ reyesdesoto@iam.csic.es \\ 3 Departamento de Geología y Geoquímica, Facultad de Ciencias, Universidad Autónoma, \\ 28049 Madrid, Spain \\ * Correspondence: rosario.garcia@uam.es
}

Received: 22 April 2019; Accepted: 22 June 2019; Published: 24 June 2019

\begin{abstract}
The present article evaluated the mineralogical composition of 85 mortar samples from some emblematic monuments of Ávila city (Spain), which were collected during the restoration of the monuments. The aim of this article is to try to extract the relationship between the composition and the origin of the raw materials, as well as to identify possible alterations in the samples. The study of the samples was carried out using visual and petrographic techniques such as stereoscopic microscope, $X R D$, and SEM/EDX analysis. The main components of the mortars were calcite, feldspar and quartz, although small amounts of phyllosilicates were also identified. The minerals of the mortars came from the surroundings of the city, and some of the samples presented evident alteration of the original materials due to humidity, salt concentration, and biological weathering, possibly inducted by unfortunate effects of the restoration. Finally, a study of the salts present in some mortars showed that most samples display contamination of soluble salts such as halite, thenardite, hexaedrite, and carnalite. This investigation offers fresh insight into historic building activity and related techniques, and should provide knowledge useful for restoration and conservation processes.
\end{abstract}

Keywords: mortars; wall; granitic rocks; Ávila; Spain

\section{Introduction}

Mortar can be defined as a material composed of crystalline and amorphous phases, containing inert and reactive aggregates in a calcitic binder. However, being an artificial product, its composition and characteristics may change depending on the construction period, location, and function. Roman mortars, due to their extraordinary durability, have attracted researchers who want to develop the most effective techniques for restoring ancient monuments. The necessary requirements to preserve old buildings in relation to the formula of the repaired mortar are the hydraulics of the binder, the proportions of the mixture (proportion of aggregates/binders), and the classification of the aggregate that allows identification of the adequate components for producing a compatible mortar.

Historical sources refer to the use of mortars as building materials in tanks, walls, aqueducts, wells, and duct drains, as support pavements and mosaics, and as plasters in external and internal walls [1-3]. They are complex systems which contain air or hydraulic binders or a mixture of both, aggregates (not always crystalline), and additives that interact with the binder. Mortars have different compositional characteristics and materials due to different construction needs and raw materials. The composition is a good indicator of the origin of the components and their construction phases [4]. 
The characterization of mortars can be achieved by integrating the results of various methods of analysis [5-7]. In relation to heritage, the study of mortars is a precise and effective documentary tool [8], which can help to interpret construction and recomposition using raw materials similar to those of the initial construction moment, as observed in the Roman city of Ammaia (Portugal) [9].

The restoration of buildings requires an advanced knowledge of construction materials. Therefore, a reliable restoration and conservation of mortars requires a knowledge of their composition [10] (e.g., a complete mineralogical characterization and a petrographic study of mortars). For this reason, studies on this have been carried out extensively focusing on some historical monuments of several cities in Spain [10-16] and around the world [9,17-25].

In this work, we present the data of 85 samples from emergency excavations of several monuments of Ávila city (Spain). Specifically, they came from several points of the city wall (Puerta del Alcazar, Puerta de San Vicente, Puerta del Carmen), the cathedral, San Pedro, and San Andrés churches (outside the walls), and from an archaeological excavation dated from the Chalcolithic age in the vicinity, called Tiro Pichón (Figure 1). All of these samples were collected during emergency excavations for restoration purposes, and they were taken by National Heritage (Ayuntamiento de Ávila) based on the necessary reconstruction interventions due to the buildings being historical monuments.
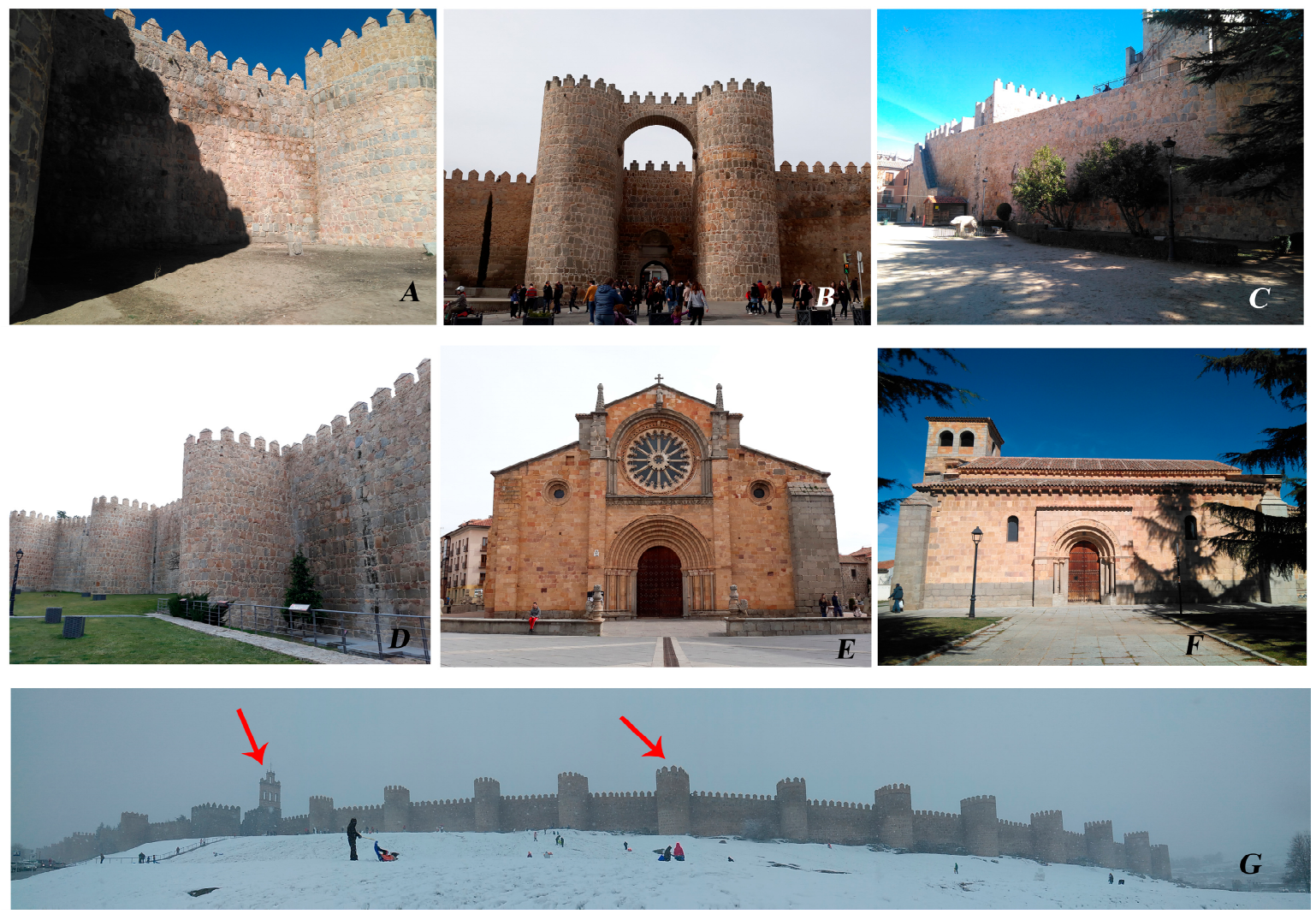

Figure 1. Ávila main monuments studied in this paper; (A-C) Puerta del Alcazar and Alcazar sites; (D) San Vicente door; (E) San Pedro church; (F) San Andrés church; (G) Puerta del Carmen and Tower number 34.

The wall is one of the best-preserved examples of this type of monument in the whole world. It has a perimeter of $2516 \mathrm{~m}$ (33 ha), 87 towers, nine doors, and two small doors. It presents an irregular rectangle shape with an East to West orientation. The cathedral stands as a church and fortress, and is considered to be the first Gothic cathedral in Spain that stands on the remains of an old church. San Pedro, outside the walls, is a Latin cross design church from the second quarter of the 12th century. The church of San Andrés is also outside the walls, and is in the Romanic style 
(12th century). All of these monuments were made with granite rocks from the surroundings of Ávila. Finally, the archaeological site of Tiro Pichón contains Chalcolithic vestiges [26].

The aim of this article is to carry out a mineralogical characterization of different types of mortars collected during emergency interventions to preserve the wall and surrounding monuments from 2007 to the present, following the directives of National Heritage for obtaining samples. In addition, this paper presents a methodological approach to group and study the technological characteristics of a large number of mortar samples, which may help us to understand the main threats to the conservation of historical monuments. This investigation offers fresh insights into historic building activity and related techniques, and should provide knowledge useful for restoration and conservation processes.

\section{Materials and Methods}

\subsection{Geological and Climatological Setting}

Ávila city is located in the Central System (Figure 2). The materials that outcrop in the studied area are amphibole-bearing granitic rocks $[27,28]$. However, near this city, two other types of rocks appear: (1) metamorphic rocks (phylites, composed of muscovite, quartz, and biotite with accessory minerals such as tourmaline and amphiboles, and quartzites composed of quartz, amphibole, and plagioclase with titanite and zircon as accessories); and (2) sedimentary rocks (conglomerates and sandstones, carbonate rocks, and quaternary detrital materials related to the installation of the current network of the river that runs through the city).

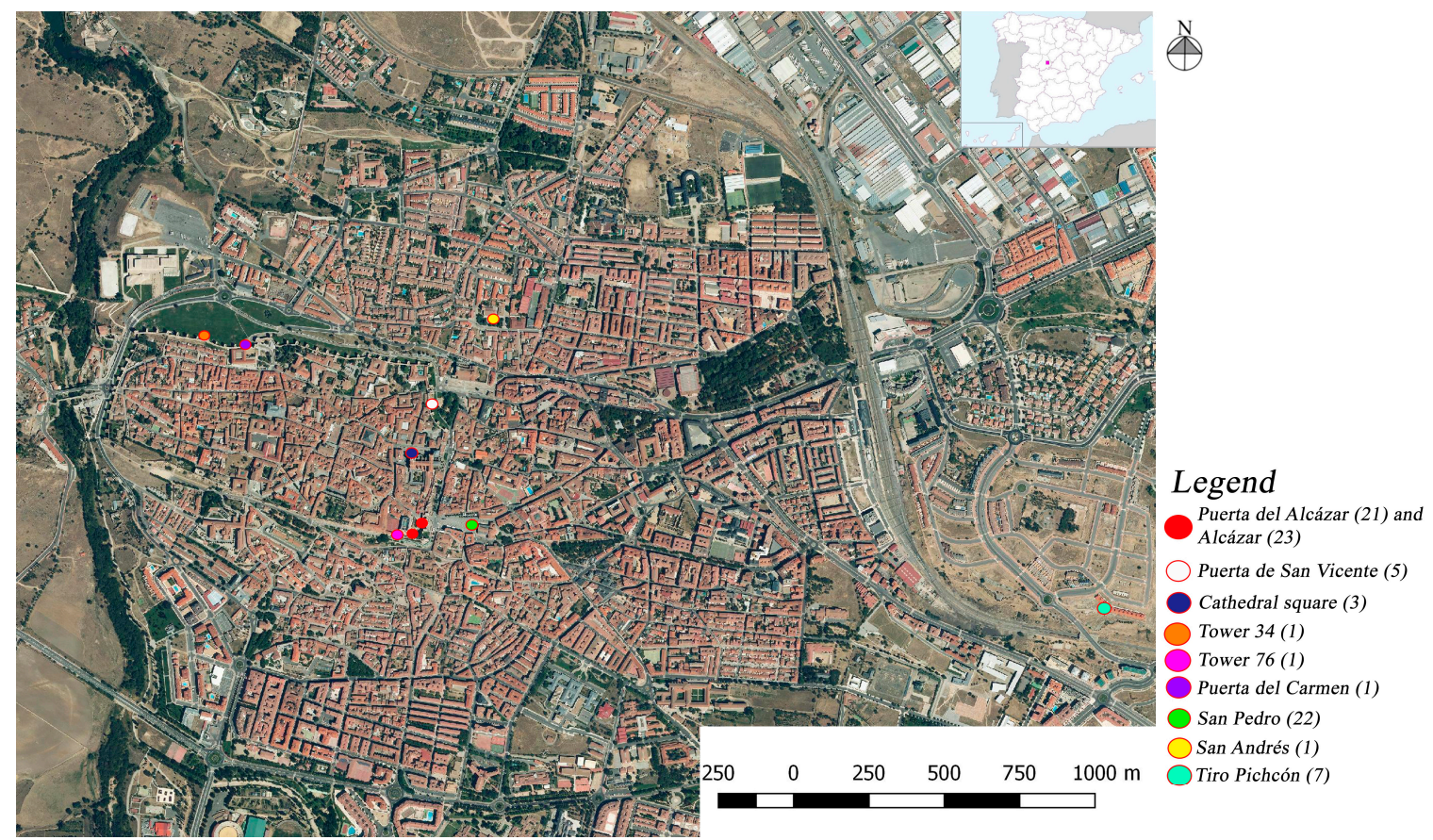

Figure 2. Location map of the studied monuments and the number of samples.

Climatologically, Ávila is Csb type according to the Köppen-Geiger classification, with a long frost period (7 months) and a series of freezing and thawing cycles of 100 cycles or more per year. These climatic characteristics can change the state of the building materials used, as was detected in this work. The climatology conditions have clearly influenced the state of the mortars, which are highly altered. Further, the union with the bricks was very poor and previous attempts to repair these mortars were not successful, showing a rapid deterioration with cracks in the mortar parallel to the bricks due to freeze damage (gelifraction). During the twentieth century, due to restoration processes, there has been a gradual replacement of lime mortars with cement-based ones. 


\subsection{Materials}

In this paper, we have analyzed lime mortars with different types of binders from emergency interventions in the Ávila wall and other historical monuments of the city. National Heritage indicated the points of sample selection, where there was ostensible deterioration. Most mortars cement the ashlars of the granite wall [29]. Figure 2 shows the number of mortars studied and their situation in the city. A total of 85 samples have been re-collected (55 from the Ávila wall, 22 samples from S. Pedro Church, 1 sample from S. Andrés church, and 7 samples from Tiro Pichón).

\subsection{Methods}

Small fragments of the mortars were observed with the naked eye and with a stereoscopic microscope to study the size, the color of the binder, and the types of aggregates using the Münsell color chart. In addition, the cohesion of the mortar was evaluated.

Thin sections (20-25 $\mu \mathrm{m}$ ) were prepared to observe their composition in a petrographic polarization microscope (Orto Plan Pol Leitz). When the thin sections were fragile, the samples were consolidated with resin and the sections were cut after drying to later perform their observation under a microscope.

Porosity and pore size distribution were investigated by mercury intrusion porosimetry, performed with a Micromeritics Auto Pore IV 9500 v1.05 (Micromeritisc, Norcross, GA, USA).

The samples were broken smoothly, obtaining fragments of mortar that were later used for observations in a scanning electron microscope. On the other hand, the material was powdered and homogenized with an agate mortar for X-ray analysis.

The mineralogical composition of the samples was resolved by powder X-ray diffraction (Malvern Panalytical, Madrid, Spain) on a PANalytical X'Pert PRO X-ray diffractometer equipped with a Cu anode. Its operating conditions were $40 \mathrm{~mA}, 45 \mathrm{kV}, 0.5^{\circ}$ divergence slit, and $0.5 \mathrm{~mm}$ slit reception. The samples were scanned with a step size of $0.0167^{\circ}(2 \theta)$ and $150 \mathrm{~ms}$ per step. The characterization of the samples was carried out using the random power method, which operates from $5^{\circ}$ to $80^{\circ}$ (20) [30]. Measured patterns were qualitatively and quantitatively analyzed using Match v.3 and Fullprof software for Rietveld analysis, respectively [31-33]. Crystallography Open Database (COD) reference patterns were used to identify the different phases.

SEM/EDX carried out morphological observations and microanalysis of the samples/EDX using an Inspect FEI Electron Microcopy (FEI, Hillsboro, OR, USA), equipped with an energy dispersive $\mathrm{X}$-ray analyzer (W source, DX4i analyzer and $\mathrm{Si} / \mathrm{Li}$ detector). The chemical composition presented is the mean value of ten analyses per sample. The results are expressed in oxides (\% by weight).

\section{Results and Discussion}

The mortar samples were pale gray (10YR 8/2 in the Munsell color chart). Under the binocular microscope, the samples were very porous, with pores covered by secondary minerals. In general, angular fragments of limestone with dark gray colors were identified, together with rounded quartz grains and angular feldspars, as well as fragments of sandstones rich in quartz and in some cases, ceramic fragments of red/orange bricks.

The results of XRD (Table 1) indicated the presence of calcite, quartz, and Na-Ca feldspar or K-feldspar, depending on its greater or lesser concentration according to the building and the wall area. It can be said that mortars are silicated to the detriment of carbonates. In some samples, the presence of clay minerals could be detected, such as illite (in most cases), smectite (only once), and kaolinite, as well as traces of gehlenite and a small amount of calcium silicate hydrate, which indicates the presence of hydraulic compounds. In addition, an amorphous phase, C-S-H gels, was identified, but was not quantified by XRD due to its amorphous nature or very low crystallinity [34]. Finally, gypsum appeared in only one sample in a small proportion (a wall sample with contemporary retouch). 
Quartz concentration showed an average between 20\%/30\%, except from the South wall and Tiro Pichón, where the greatest proportion was phyllosilicates. All the samples had high concentrations of feldspars except for the sample from the South wall, which was eminently carbonated.

Figure 3 shows the mineralogical compounds in a box and whisker plot, made with the mineralogical data obtained by XRD of all the samples. These graphs are among the most used methods for the visualization of univariate data. Therefore, in this paper they were used to evaluate the homogeneity or heterogeneity of the samples in relation to their mineralogical composition. It can be observed that the samples were quite heterogeneous, because a notable variability was found for the concentrations of quartz, K-feldspar, Na-Ca feldspar, and calcite. Furthermore, the variability of the content of phyllosilicates, dolomite, and gypsum was moderate.

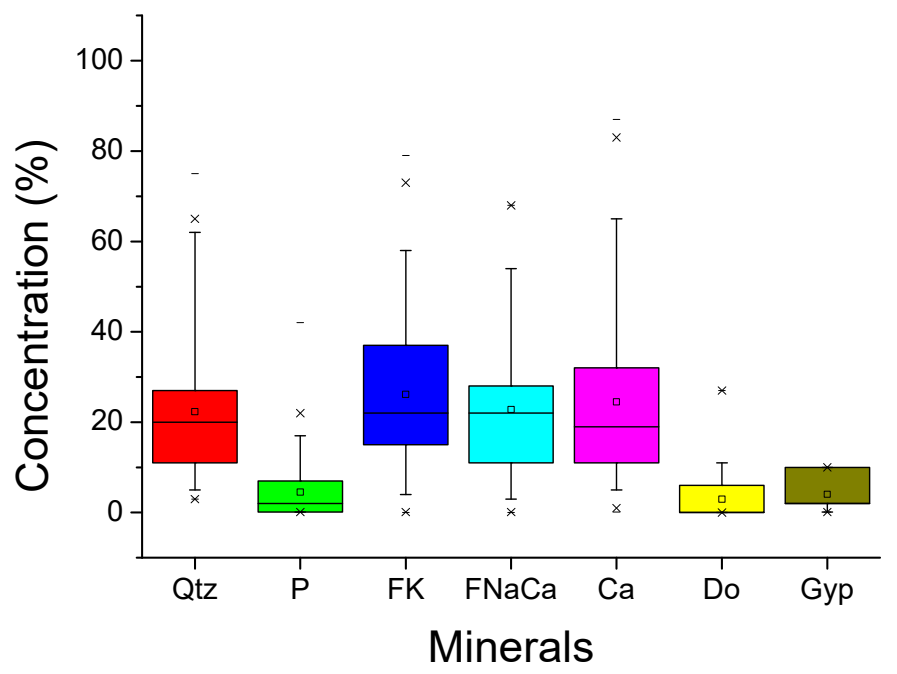

Figure 3. Box and whisker analysis of the samples (Qtz: Quartz; P: Phyllosilicates; FK: K feldspars; FNaCa: Na, Ca feldspars; Ca: Calcite; Do: Dolomite; Gyp: Gypsum).

Table 1. Mineralogical composition of samples by XRD analysis (n.d. = not detected).

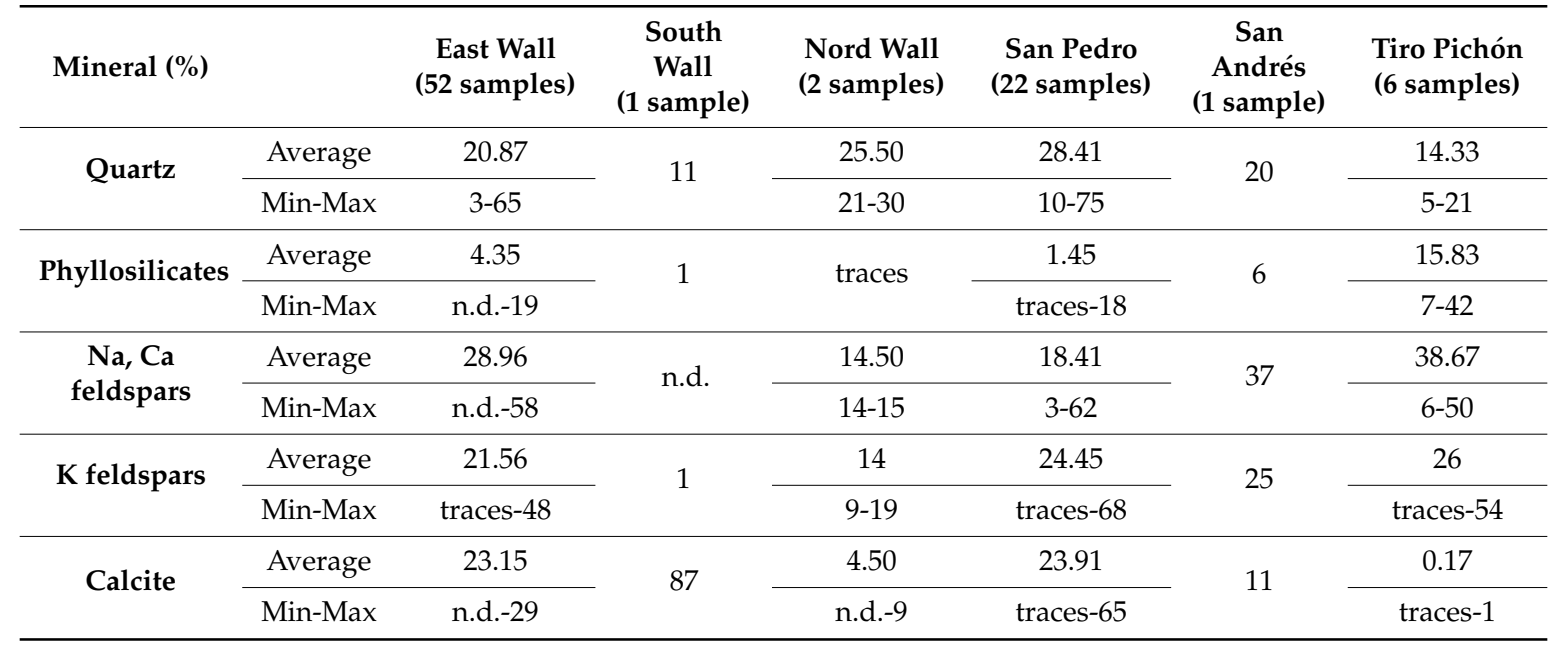

Regarding the relationship between the mineralogical data and the geology of Ávila city, most of the minerals found in the mortars can be found near Ávila city, which could mean that the samples were local.

CSH gels appear in all samples. The strength and durability of the mortar is attributed to the presence of reactive components in the material that, in mixtures with a calcium hydroxide base, react to form calcium silicate hydrates, commonly called CSH gels [35]. The mineralogical composition of the cements is due to a characteristic mechanism of two stages of hydration, and development of 
resistance. First, the cement pastes harden a few minutes after the initial setting. Secondly, after a period of inactivity dependent on the conditions of the cement source and the calcination, a further development of resistance takes place leading to the final compressive strength values. The final resistance is due to the hydration of the dicalcium silicate (belite), which produces calcium silicate hydrates (CSH gels). The two-stage mechanism of cement hydration is shown in a characteristic development of the pore structure [35].

By contrast, the calcium carbonate present in the samples must be attributed to the carbonation of calcium hydroxide; that is, to the reaction with $\mathrm{CO}_{2}$, which is responsible for the hardening of lime mortars. After about 15 centuries, based on the hypothesized date of the mortar mix, the original crystalline off white lime, portlandite $\left(\mathrm{Ca}(\mathrm{OH})_{2}\right)$, could not be found. The binding material is calcite, which is finely crystallized. This indicates a high, almost total, conversion of calcium hydroxide to calcium carbonate by atmospheric $\mathrm{CO}_{2}$.

Petrographic observations also revealed a certain variability, since they are heterogeneous in terms of granulometry and pore size. Figure 4 shows the petrographic observation. On the left, homogenous and compact micritical lime binders were detected. The porosity was medium (on average 34\%, mainly vesicles and pores of irregular shape) with a cryptocrystalline appearance. On the right, there was a micritic or microsparitic binder with rounded fragments of quartz and feldspars.
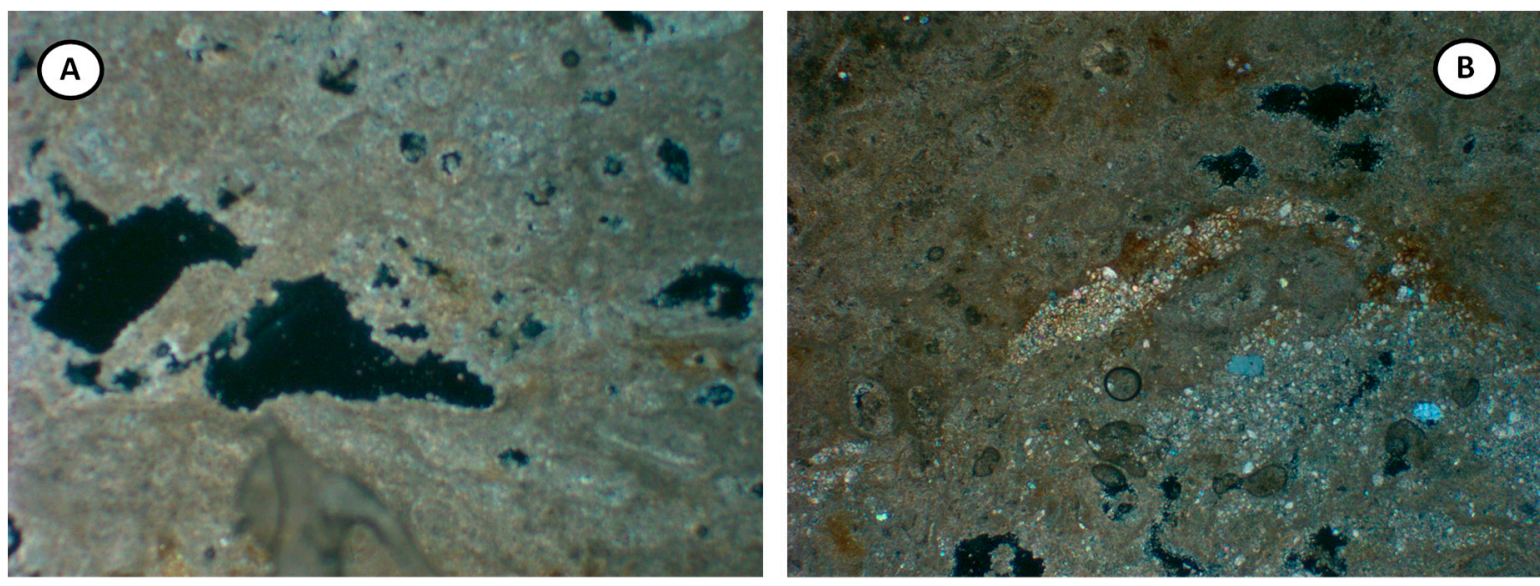

Figure 4. Petrographic observation. (A) Homogeneous binder. (B) Heterogeneous binder (Observation X 64 and polarizing light).

The main factor for the maintenance of historic buildings is the use of compatible materials during restoration phases. The porosity and the structure of the pores are essential characteristics when studying the resistance to water and the permeability of the mortar. The porosimetric analysis indicated that lime mortars made with silica-rich aggregates had pores with radii between 1 and $10 \mu \mathrm{m}$. The larger pores were due to the poor cohesion between the matrix and the silicic-aggregate grains, and the consequent formation of retraction fissures [36].

The size of the aggregates varied from very fine to coarse sand, indicating a poorly classified material, with darker lithic clasts, and predominantly rounded/sub-angular. The dominant aggregate grains were coarse grains of quartz sand, together with quartz-rich sandstones, fragments of dark gray rock or even, in some cases, red ceramic fragments.

Mineralogical analysis indicated that the aggregate grains of sand were dominated by silicate minerals, such as moderately rounded quartz, with Na-Ca feldspars (plagioclase) and K-feldspar.

It can be said that different materials were used both for the construction of the monuments and for the restoration tasks. In addition, the state and the geochemical evolution of the materials were quite different. A great variability in the mineral composition of the samples could be found. The monuments of Ávila have different ages, and numerous periods of reconstruction have been carried out throughout the history of the city [37-42] since the origin of "Obila" (Ávila) in the first 
century before Christ [43]. For example, over just 19 years (from 1998 to 2007), 140 archaeological interventions were developed for the construction of new buildings or public building restoration [44]. In addition, in some cases, materials from ancient monuments were used for the reconstruction of a current monument [42].

Our results agree with the conclusions obtained by García-Talegón [37] regarding the Cathedral of Ávila. Although the main objective of that article was to study the use of three well-differentiated granite rocks in detail, they also studied the mortars of this building. It was shown that several periods of construction and reconstruction were carried out in the construction of the Cathedral, using different materials in each period.

Historical mortars were created after a careful selection of their raw materials, and were fully compatible with the rest of the factory elements. However, nowadays, they are typically replaced with cement mortars, which are very incompatible with the other factory elements in spite of their very good physical-mechanical properties, since they also produce a strong visual impact and generate soluble salts that lead to disastrous consequences for the architectural heritage of a location [45]. This supports evidence for the existence of gypsum in a single sample from the wall from a current reconstruction (mortar with gypsum).

Another reason for the mineral variability could be the different geochemical evolutions of the minerals from the mortars. There have been many biogeochemical processes occurring in the materials of the Ávila monuments over time, such as the dissolution/precipitation of minerals, the alteration of the rock due to chemical weathering, the formation of lichens, and the effects of humidity [46-48]. These processes can transform the original minerals into other materials. Some of these processes have been recently studied using an architectural orthophoto plan for the pathological characterization of the wall [46-48], and this technique confirms the existence of these biogeochemical processes in the wall.

Mortar studies in other Ávila samples confirmed that the lower proportions in the lime/sand ratio correspond to the higher humidity locations, and this fact prevents the possibility of estimating the initial lime/sand ratio on a global scale, since the lime turns to carbonate [49].

Recently, the threats and agents of deterioration that are affecting the Ávila monuments have been grouped into the categories of natural and anthropic. Among the natural issues we can find humidity, temperature, radiation, wind, and biological and geotechnical factors. In contrast, the anthropic factors are vibrations, the mechanical impact of traffic, air pollution, fires, vandalism, and the negative effects of previous repairs that we have already described [50]. One of the most important threats is the presence of salts that affect the mortars, degrading them until they lose their consistency. For this reason, in this article, we have studied the salt content of the samples.

SEM/EDX analysis showed concentrations of soluble salts such as halite, thenardite, hexahydrite, and carnallite. Its presence and its continuous process of dissolution/crystallization are associated with the gradual wear of the mortars. The salt could come from the road salt added during the winter season in Ávila due to low temperatures (around 100 cycles of freezing and thawing per year). Although there is no information available on the impact of road salt on historic buildings, the impact of this activity is demonstrated in urban soils, living water organisms, and some forms of infrastructure [51-53]. Therefore, this addition of salt may have a negative effect on monuments, and this should be considered in the future.

Halite is a highly soluble salt. In the analyzed samples, rounded and smooth morphological surface covered pores and fractures coexisted with $\mathrm{NaCl}$ cubic crystals. In addition, the complete carbonate series (vaterite, hemihedrite, and aragonite) was recognized. This fact can be explained by the different hydration phases of calcite, due to the environmental humidity conditions.

The origin of sulphates must be attributed to the construction materials used, whether in the presence of gypsum mortar or gypsum fragments between the aggregate. Gypsum has a very low solubility in dry environments; the presence of halite, more hygroscopics decreases its moisture of deliquescence, with a consequent increase in solubility. 
Some samples of rich-in-salt compositions are found in tower 44 (Figure 2), in the area near the Adaja river bridge, with thenardite (11\%), quartz (22\%), calcite (38\%), and K-feldspar (29\%). The same is present in the tower 66 sample.

The morphological study by SEM/EDX of the mentioned mortars indicated aggregates of porous salts with poorly defined grain boundaries and rounded shapes, possibly indicative of dissolution processes (Figure 5, left and right). These aggregates were composed of sulfates, sodium and potassium chloride mixtures (Table 2).

Table 2. Chemical analysis by $\mathrm{X}$-ray dispersive energies from the tower number 44 sample.

\begin{tabular}{cccc}
\hline Oxides & Thenardite & Amorphous Deposit & Rounded Grains \\
\hline $\mathrm{Na}_{2} \mathrm{O}$ & 37.25 & 43.78 & 32.15 \\
$\mathrm{SO}_{3}$ & 36.32 & n.d. & 9.34 \\
$\mathrm{~K}_{2} \mathrm{O}$ & 14.04 & 19.97 & 47.04 \\
$\mathrm{Cl}^{-}$ & 12.39 & 36.24 & 11.47 \\
\hline
\end{tabular}

n.d. = not detected.
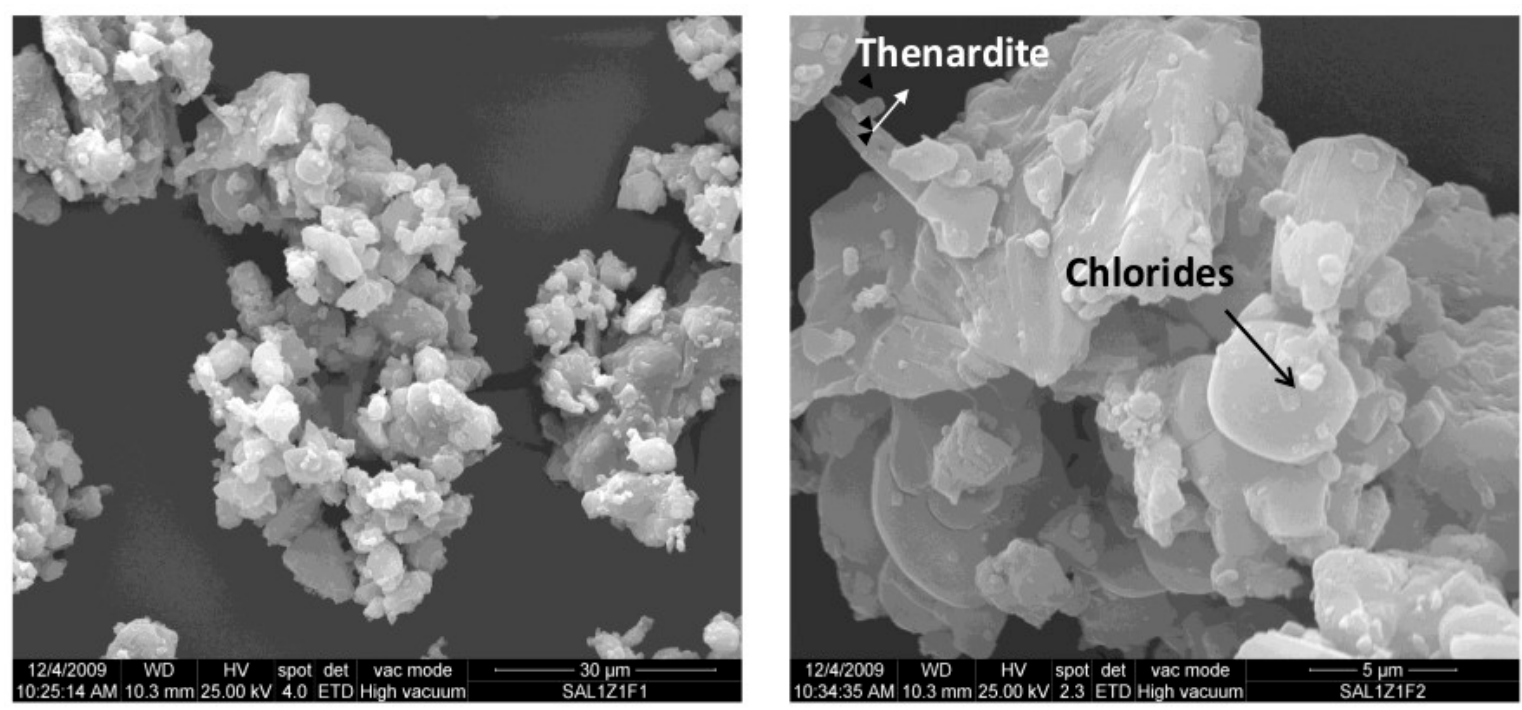

Figure 5. General aspect of the aggregates (Left); Laminated grain edges (Right), detail.

Thenardite crystals had elongated and prismatic forms within these aggregates (Figure 6, top right, Table 3), while the amorphous and strongly coiled deposits were enriched in chlorine and potassium (Figure 6, top left and right, Table 3).

Samples collected from the 76/77 canvas from the East wall (with thenardite, halite, and calcite) and the 66/67 canvas sample (East wall) contained illite, hexahydrite, gypsum, quartz, feldspar, carnallite, and bloedite. The morphological study by SEM/EDX showed aggregates with better-defined grain boundaries and sub-angular planes, although the forms were, in general, rounded (Figure 6). The very rounded grains were composed of sodium and potassium chlorides. Hexahydrite was formed from aggregates rich in sulfates and chlorides (Figure 6, top right, and Table 3). Thenardite maintained, in these aggregates, the prismatic shape (Figure 6, upper right, and Table 3). Micas, feldspars, and quartz grains retained their defined edges in the aggregates, however, they showed, on their surfaces, the corrosion marks indicative of the dissolution processes (Figure 6, below, and Table 3). The sulphates showed a composition of $\mathrm{K}$ and Na sulphate (Figure 7, left), and the feldspars, in the sand, showed surface corrosion marks (Figure 7, right). 

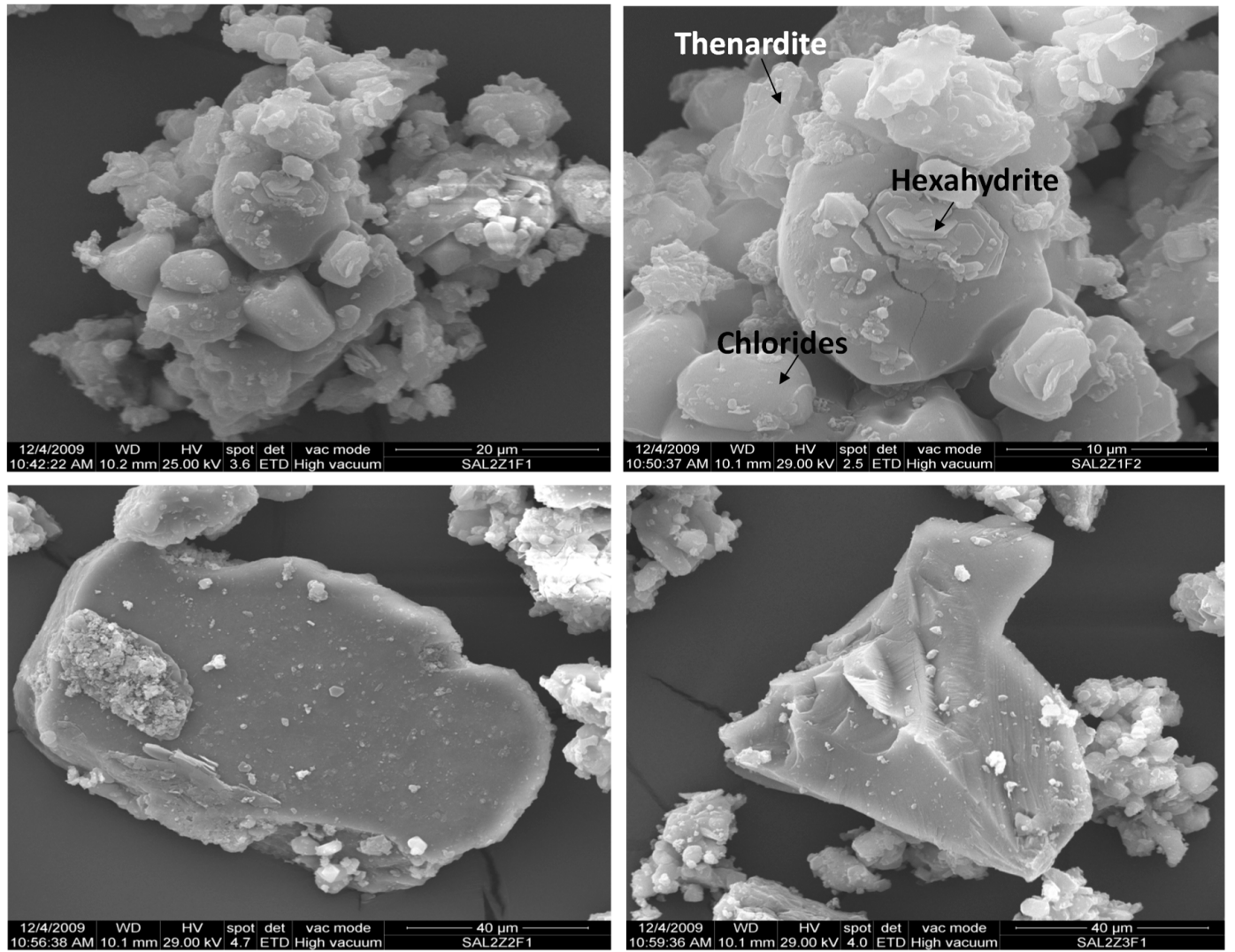

Figure 6. Top (left) aggregates, general appearance, (Right) hexahydrite formation; Bottom (left) mica, general appearance, (Right) dissolution marks in quartz.

Table 3. Chemical analysis by X-ray dispersive energies from the 66/67 and 76/77 canvas samples.

\begin{tabular}{ccccccc}
\hline Oxides & Thenardite & K-feldspar & Hexahydrite & Chloride & Mica & Sulphate \\
\hline $\mathrm{Na}_{2} \mathrm{O}$ & 45.18 & n.d. & 14.24 & 28.70 & n.d. & 11.75 \\
$\mathrm{MgO}$ & n.d. & n.d. & 4.13 & n.d. & 8.11 & 4.35 \\
$\mathrm{SO}_{3}$ & 17.04 & n.d. & 33.54 & n.d. & n.d. & 55.82 \\
$\mathrm{~K}_{2} \mathrm{O}$ & 18.81. & 24.13 & 15.66 & 28.24 & 10.02 & 20.56 \\
$\mathrm{Cl}^{-}$ & 8.77 & 1.11 & 11.06 & 43.06 & n.d. & 1.76 \\
$\mathrm{Al}_{2} \mathrm{O}_{3}$ & n.d. & 13.55 & n.d. & n.d. & 12.55 & n.d. \\
$\mathrm{SiO}_{2}$ & 3.09 & 61.21 & 3.18 & n.d. & 39.26 & 2.35 \\
$\mathrm{CaO}$ & n.d. & n.d. & 18.19 & n.d. & n.d. & 3.40 \\
$\mathrm{Fe}_{2} \mathrm{O}_{2}$ & n.d. & n.d. & n.d. & n.d. & 25.02 & n.d. \\
$\mathrm{TiO}_{2}$ & n.d. & & n.d. & n.d. & 5.04 & n.d. \\
\hline
\end{tabular}

n.d. $=$ not detected.
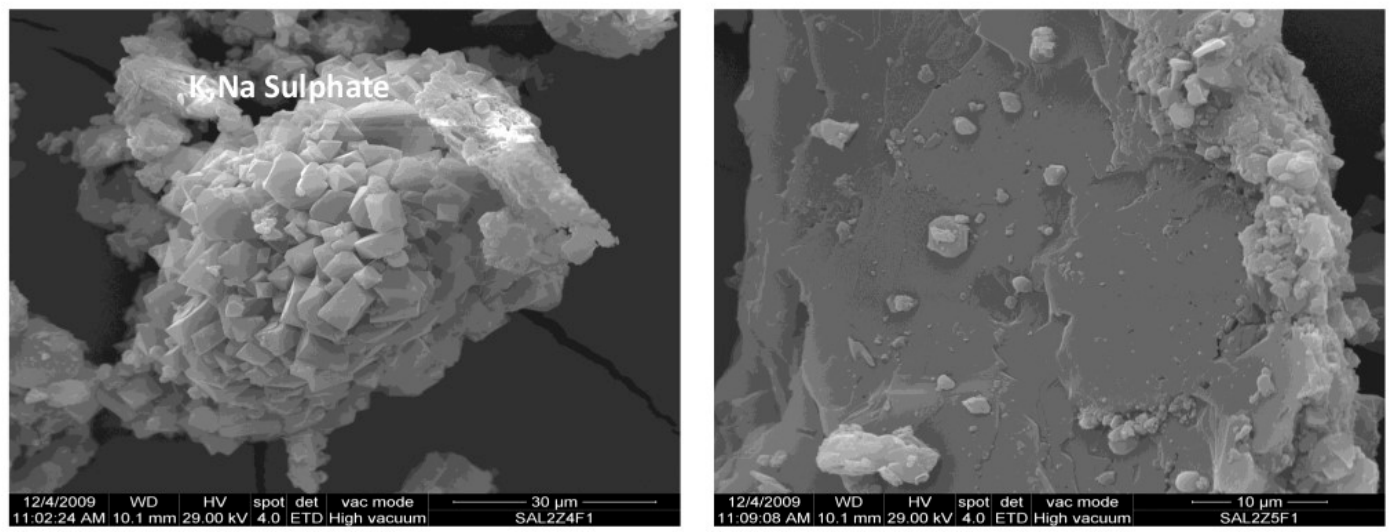

Figure 7. (Left) K, monoclinic crystals of Na sulfate. (Right) marks of surface corrosion in feldspars. 


\section{Conclusions}

Mortars, as artificial cementitious materials, preserve the technological footprint that humans give them. These materials, due to their compositional complexity, reveal vestiges of the technological background of certain historical periods. As observed in other studies of historical mortars [54], they include binder and aggregate components strictly related to the lithology outcroppings in the surroundings, plus additional components arising from secondary processes. Such investigations offer fresh insight into historic building activity and related techniques, and should provide knowledge that is useful for restoration and conservation processes.

The main components of the mortars from monuments studied in Ávila were feldspars, calcite and quartz, although small amounts of phyllosilicates and dolomite were also identified. All of these minerals come from the Ávila region: they are local mortars. The important concentration of carbonates (mainly calcite) means that the lime from the mortars has been converted into carbonates.

Mineralogical variability, in terms of proportion, in the studied mortars is related to:

- Alteration of mortars mainly due to humidification and salt concentrations. In addition, other biogeochemical processes have occurred, such as biological weathering (the role of lichens).

- The use of different raw materials for the construction and for numerous restoration events throughout the history of the city.

Finally, some samples show the contamination of soluble salts, such as halite, thenardite, hexahydrite and carnallite, and this additional salt concentration could be attributed to the aggregate road salt used in Ávila during the winter season. Therefore, its use could have a negative effect on the local monuments, and this should be considered for future studies because it was observed in this study to be a major threat in terms of deterioration.

Author Contributions: I.S.d.S.G. has carried out the interpretation of the data and the writing of the work. M.d.1.R.d.S.G. has described and collected the samples and R.G.G. has analyzed the samples and interpreted the results.

Acknowledgments: We appreciate the sampling and comments that Blas Cabrera (Castellum scoop.) has provided us.

Conflicts of Interest: The authors declare no conflict of interest.

\section{References}

1. Miriello, D.; Barca, D.; Bloise, A.; Ciarallo, A.M.; Crisci, G.M.; De Rose, T.; Gattuso, C.; Gazineo, F.; La Russa, M.F. Characterization of archaeological mortars from Pompeii (Campania, Italy) and identification of construction phases by compositional data analysis. J. Archae. Sci. 2010, 37, 2207-2223. [CrossRef]

2. Kramar, S.; Zalar, V.; Urosevic, M.; Körner, W.; Mauko, A.; Mirtič, B. Mineralogical and microstructural studies of mortars from the bath complex of the Roman villa rustica near Mošnje (Slovenia). Mater. Charact. 2011, 62, 1042-1057. [CrossRef]

3. Leonea, G.; De Vitab, A.; Magnania, A.; Rossia, C. Characterization of archaeological mortars from Herculaneum. Thermochim. Act. 2016, 624, 86-94. [CrossRef]

4. Moropoulou, A.; Bakolas, A.; Anagnostopoulou, S. Composite materials in ancient structures. Cem. Concr. Comp. 2005, 27, 295-300. [CrossRef]

5. Miranda, J.; Carvalho, A.P.; Pires, J. Assessment of the binder in historical mortars by various techniques. Archaeometry 2012, 54, 267-277. [CrossRef]

6. Middendorf, B.; Hughes, J.J.; Callebaut, K.; Baronio, G.; Papayianni, I. Investigative methods for the characterisation of historic mortars-Part 1: Mineralogical characterization. Mat. Struct. 2005, 38, 771-780. [CrossRef]

7. Middendorf, B.; Hughes, J.J.; Callebaut, K.; Baronio, G.; Papayianni, I. Investigative methods for the characterisation of historic mortars-Part 2: Chemical characterization. Mat. Struct. 2005, 38, 761-769. [CrossRef] 
8. Rodríguez Gordillo, J.F. Morteros como elementos de estudio en Arqueología-Arqueometría Medieval. In Arqueometría y Arqueología Medieval; Baraka, A., Ed.; Universidad de Granada: Granada, Spain, 2005; pp. 171-192.

9. Cardoso, I.; Macedo, M.F.; Vermeulen, F.; Corsi, C.; Santos Silva, A.; Rosado, L.; Candeias, A.; Mirao, J. A multidisciplinary aproach to the study of Archaeological mortars from the town of Ammaia in the Roman province of Lusitania (Portugal). Archaeometry 2014, 56, 1-24. [CrossRef]

10. Gutiérrez-Solana, F.; Jauregui, M.; Bohigas, R.; Sarabia, P. Análisis de morteros medievales de dos castillos de Cantabria (España). Mat. Construc. 1989, 213, 37-45.

11. Álvarez, J.I.; Navarro, I.; Martín, A.; García Casado, P.J. A study of the ancient mortars in the north tower of Pamplona's San Cernin church. Cem. Concr. Res. 2000, 30, 1413-1419. [CrossRef]

12. Álvarez, J.I. Caracterización fisicoquímica, mecánica y de durabilidad de morteros de cal en monumentos del Románico en Navarra. In V Jornada de Técnicas de Restauración y Conservación del Patrimonio; Instituto del Patrimonio Cultural de España: Madrid, Spain, 2006.

13. Sanjurjo-Sánchez, J.; Trindade, M.J.; Blanco-Rotea, R.; Garcia, R.B.; Mosquera, D.F.; Burbidge, C.; Dias, M.I. Chemical and mineralogical characterization of historic mortars from the Santa Eulalia de Bóveda temple, NW Spain. J. Archaeol. Sci. 2010, 37, 2346-2351. [CrossRef]

14. Ontiveros-Ortega, E.; Rodríguez-Gutiérrez, O.; Navarro, A.D. Mineralogical and physical-chemical characterisation of Roman mortars used for monumental substructures on the Hill of San Antonio, in the Roman city of Italica (prov. Baetica, Santiponce, Seville, Spain). J. Archaeol. Sci. Rep. 2016, 7, $205-223$. [CrossRef]

15. Gallello, G.; Ramacciotti, M.; Lezzerini, M.; Hernandez, E.; Calvo, M.; Morales, A.; Pastor, A.; de la Guardia, M. Indirect chronology method employing rare earth elements to identify Sagunto Castle mortar construction periods. Microchem. J. 2017, 132, 251-261. [CrossRef]

16. Lubritto, A.; Ricci, P.; Germinario, C.; Izzo, F.; Mercurio, M.; Langella, A.; Salvatierra Cuenca, V.; Montilla Torres, I.; Fedi, M.; Grifa, C. Radiocarbon dating of mortars: Contamination effects and sample characterisation. The case-study of Andalusian medieval castles (Jaén, Spain). Measurement 2018, 118, 362-371. [CrossRef]

17. Moropoulou, A.; Bakolas, A.; Bisbikou, K. Investigation of the technology of historic mortars. J. Cult. Her. 2000, 1, 45-58. [CrossRef]

18. Schueremans, L.; Vangenechten, B. The use on 3D-laser scanning in assessing the safety of masonry vaults-A case study on the church of Saint-Jacobs. Opt. Lasers Eng. 2009, 47, 329-335. [CrossRef]

19. Bany Yaseen, I.A.; Al-Amoush, H.; Al-Farajat, M.; Mayyas, A. Petrography and mineralogy of Roman mortars from buildings of the ancient city of Jerash. Jordan. Constr. Buil. Mat. 2013, 38, 465-471. [CrossRef]

20. Bertolini, L.; Carsana, M.; Gastaldi, M.; Lollini, F.; Redaelli, E. Binder characterisation of mortars used at different ages in the San Lorenzo church in Milan. Mat. Charact. 2013, 80, 9-20. [CrossRef]

21. Theodoridou, M.; Ioannou, I.; Philokyprou, M. New evidence of early use of artificial pozzolanic material in mortars. J. Archae. Sci. 2013, 40, 3263-3269. [CrossRef]

22. Pintér, F.; Vidovszky, I.; Weber, J.; Bayer, K. Mineralogical and microstructural characteristics of historic Roman cement renders from Budapest, Hungary. J. Cult. Her. 2014, 15, 219-226. [CrossRef]

23. Hormes, J.; Diekamp, A.; Klysubun, W.; Bovenkamp, G.L.; Börste, N. The characterization of historic mortars: A comparison between powder diffraction and synchrotron radiation based X-ray absorption and X-ray fluorescence spectroscopy. Microchem. J. 2016, 125, 190-195. [CrossRef]

24. Raposo, P.C.; Correia, J.A.F.O.; Sousa, D.; Salavessa, M.E.; Reisa, C.; Oliveira, C.; de Jesus, A. Petrographic characterization of partition wall mortars of a 19th Century building. Proc. Struct. Integ. 2017, 5, 1092-1096. [CrossRef]

25. Borsoi, G.; Santos Silva, A.; Menezes, P.; Candeias, A.; Mirão, J. Analytical characterization of ancient mortars from the archaeological roman site of Pisões (Beja, Portugal). Constr. Buil. Mat. 2019, 2014, 597-608. [CrossRef]

26. Blanco González, A. El Poblamiento del Bronce Final y Primer Hierro en el Sector Meridional de la Submeseta Norte. Ph.D. Thesis, University of Salamanca, Salamanca, Spain, 2009.

27. Mapa Geológico de España 1:50000-Hoja 531-Ávila de los Caballeros; Instituto Geológico y Minero de España (IGME): Madrid, Spain, 2008. 
28. Bea, F.; Montero, P.; Molina, J.F. Mafic Precursors, Peraluminous Granitoids, and Late Lamprophyres in the Avila Batholith: A Model for the Generation of Variscan Batholiths in Iberia. J. Geol. 1999, 107, 399-419. [CrossRef]

29. García Giménez, R.; Vigil de la Villa, M.; Rubio, V.; Caballero, J. Lixiviación de granitos históricos. Macla 2008, 9, 109-110.

30. Moore, M.; Reynolds, R.C. X-ray Diffraction and the Identification and Analysis of Clay Minerals, 2nd ed.; Oxford University Press: Oxford, UK, 1997.

31. Rietveld, H.M. A profile refinement method for nuclear and magnetic structures. J. Appl. Crystal. 1969, 2, 65-71. [CrossRef]

32. García, R.; Vigil de la Villa, R.; Frías, M.; Rodríguez, O. Mineral phases formation on the pozzolan/lime/water system. Appl. Clay Sci. 2009, 43, 331-335. [CrossRef]

33. García Giménez, R.; Rodríguez Largo, O.; Vigil de la Villa, R.; Frías, M. Changes to the triaxial composition of the hydrated phases $\left(\mathrm{CaO} / \mathrm{Al}_{2} \mathrm{O}_{3} / \mathrm{SiO}_{2}\right)$ in the metakaolin/lime system. J. Am. Cer. Soc. 2012, 95, 1118-1122. [CrossRef]

34. Taylor, H.F.W. Cement Chemistry, 2nd ed.; Thomas Telford: London, UK, 1997.

35. Vigil de la Villa, R.; Rodríguez, O.; García, R.; Frías, M. Mineral phases in an activated kaolinitic waste blended cement system. Appl. Clay Sci. 2010, 50, 137-142. [CrossRef]

36. Arizzi, A.; Cultrone, G. La Influencia de la Interfase Árido-Matriz (ITZ) en las Propiedades de Morteros de Cal. Macla 2012, 16, 60-61.

37. García-Talengón, A.C.; Iñigo, A.C.; Vicente, M.A.; Vargas, M.; Pérez-Rodríguez, J.L.; Molina, E. Granites employed in Avila-Spain. Mat. Construc. 1994, 44, 23-28.

38. Fernández Suárez, J.; Fernández Tresguerres, R.; Somoza Arias, L. Restauración de la Iglesia de San Pedro, en Ávila. Mat. Construc. 2012, 35, 49-57. [CrossRef]

39. González de la Granja, M.E. Construcción y evolución temporal de la muralla de Ávila: Últimas aportaciones históricas. Norba-Arte. 2010, 30, 9-24.

40. García, A.; Grande, G.; Feduchi, P.; García, A.; Sanchidrián, C. Consolidación y restauración de las murallas de Ávila. CERCHA Rev. Aparejadores y Arquitectos Téc. 2012, 114, 68-75.

41. Arrabal, R. Intervenciones Contemporáneas en la Muralla de Ávila; Trabajo Fin de Grado, Escuela técnica Superior de Arquitectura; Universidad Politécnica de Madrid: Madrid, Spain, 2017.

42. Escudero Navarro, Z. Una puerta fortificada en la catedral de Ávila. Nuevos datos sobre su primitiva fachada. Est. Patr. Cult. 2017, 16, 50-82.

43. Quintana López, J.; Centeno Cea, I.; Ruiz Entrecanales, R. El nacimiento de la ciudad de Ávila. Nuevos datos a partir de las cerámicas del Mercado Grande. BSAA 2003-2004, 69-70, 147-178.

44. Fabián, J.F. Los orígenes de la Ciudad de Ávila. De la Arqueología al esclarecimiento a la etapa Medieval. In Ávila en el Tiempo. Homenaje al ProfesorÁngel Barrios; Institución Gran Duque de Alba: Ávila, Spain, 2007; Volume 1, pp. 83-112.

45. Cazalla, O. Morteros de cal. Aplicaciones en el Patrimonio Histórico. Ph.D. Thesis, Universidad de Granada, Granada, Spain, 2002.

46. Rodríguez-Gonzálvez, P.; Mancera-Taboada, J.; González-Aguilera, D.; Muñoz-Nieto, Á.; Reguilón-Bragado, R.; Rodríguez-Bouzo, L.; Picón-Cabrera, I. Architectural orthophoto plan for pathological characterization of the Medieval Wall of Ávila. In Proceedings of the 16th International Conference on Virtual Systems and Multimedia, VSMM 2010, Seoul, Korea, 20-23 October 2010; pp. 148-154.

47. Marcos-Laso, B.; Reguilón, R. Biota Líquenica que coloniza la muralla de Ávila (España) previa restauración. In Proceedings of the XIX Congreso de Botánica Criptogámica, Las Palmas de Gran Canaria, Spain, 24-28 June 2013; p. 16.

48. Saiz-Jimenez, C. Biogeochemistry of Weathering Processes in Monuments. Geomicrob. J. 1999, $16,27-37$. [CrossRef]

49. Cuevas, J.; Vigil de la Villa, R.; García, R. Alteración de morteros como análogo natural de la longevidad de matrices inmovilizantes para residuos peligrosos. Macla 2008, 9, 73-74.

50. Ruiz Entrecanales, R. Muralla y Ciudad. In Simposium Internacional de Murallas; Ministerio de Educación, cultura y deporte: Ávila, Spain, 2016; pp. 181-202.

51. Ramakrishna, D.M.; Viraraghava, T. Environmental Impact of Chemical Deicers-A Review. Water Air Soil Pol. 2005, 166, 49-63. [CrossRef] 
52. Cunningham, M.A.; Snyder, E.; Yonkin, D.; Ross, M.; Elsen, T. Accumulation of deicing salts in soils in an urban environment. Urban Ecosyst. 2008, 11, 17-31. [CrossRef]

53. Pieper, K.J.; Tang, M.; Jones, C.N.; Weiss, S.; Greene, A.; Mohsin, H.; Parks, J.; Edwards, M.A. Impact of Road Salt on Drinking Water Quality and Infrastructure Corrosion in Private Wells. Environ. Sci. Tech. 2018, 52, 14078-14087. [CrossRef]

54. Bianchini, G.; Marrocchino, E.; Vaccaro, C. Chemical and mineralogical characterization of historic mortars in Ferrara (northeast Italy). Cem. Concr. Res. 2004, 34, 1471-1475. [CrossRef]

(C) 2019 by the authors. Licensee MDPI, Basel, Switzerland. This article is an open access article distributed under the terms and conditions of the Creative Commons Attribution (CC BY) license (http://creativecommons.org/licenses/by/4.0/). 